\title{
Commute Time Decisions in Dual-Worker Households
}

\author{
Nur Hilda Triany, Chotib Chotib*
}

\author{
Faculty of Economics and Business, Universitas Indonesia, Depok, Indonesia \\ *Corresponding author. Email: chotib@hotmail.com
}

\begin{abstract}
This study empirically examines the choice of residence in reference to differences in income and evaluates how socio-economic characteristics affect the commute time of dual-worker couples. This study used data from the 2018 National Labor Force Survey (Sakernas). The sample used in this study was workers who commuted to the place of employment and who were married household heads and their partners. The relationship was husband and wife living in in the same household. The multinomial logistic regression model was used to analyze and indicate that commuting travel differences in dual-worker households are significantly affected by differences in income, housing rental prices, differences in working hours, differences in employment status, differences in education, and location of residence.
\end{abstract}

Keywords: Dual-Worker, Commute Time, Residential Location, The Income Gap

\section{INTRODUCTION}

Big cities have developed in Indonesia into economic centers, which has resulted in changes in land use not only in urban areas but also in suburban areas. Former residential areas in urban areas have turned into office areas. The suburbs have also experienced changes from land that was originally agricultural land into residential land. Urban areas are considered to offer opportunities for a better life because of readily available employment, accessible public services, and a better level of income compared to life in rural areas. According to the data presented by the Central Bureau of Statistics, the urban populations are growing year by year. The results of the Population Census showed that 42.43 percent of the population lived in urban areas in 2000. This figure increased in 2010 to 49.8 percent, and in 2015 the percentage of people living in cities was 53.3 percent. This number is projected to increase until 2035, when it is predicted to reach 66.6 percent (BPS, 2019).

An urban population above 50 percent will cause urban sprawl problems. Population movements not only occur in the center of a metropolitan city but also in suburban areas. Some people feel boredom living in the center of the city so they move to suburban areas. The periphery develops rapidly into urban areas so that the core economic boundaries of the city extend to suburban areas. In Indonesia, the phenomenon of urban sprawl has occurred in metropolitan areas such as Jabodetabek (Jakarta, Bogor, Depok, Tangerang, and Bekasi), Bandung Raya (Bandung, Sumedang, and Cimahi), Kedungsepur (Kendal, Demak, Ungaran, Semarang, and Purwodadi), Gerbangkertosusila (Gresik,

Bangkalan, Mojokerto, Surabaya, Sidoarjo, and Lamongan), Mebidang (Medan, Binjai, and Deliserdang), Palapa (Padang, Pariaman, and Padang Pariaman), Raya Agung Statue (Palembang, Banyu Asin, Ogan Ilir, and Ogan Komering Ilir), Sarbagita (Denpasar, Badung, Gianyar, and Tabanan), Mamminasata (Makassar, Maros, Gowa, and Takalar) and Banjar Bakula (Banjarmasin, New Banjar, Banjar, Barito Kuala, and Tanah Laut).

Regional differences in Indonesia result in different patterns of mobility between regions. Changes in mobility patterns are also due to diminishing residential land in urban areas followed by high housing prices and a high cost of living and improvements in transportation facilities. Employment distribution that crosses geographical boundaries, ownership of motor vehicles, and the diversity of means of transportation contribute significantly to the process of labor mobility. This accessibility then changes the pattern of mobility to be non-permanent, which means people commute to a place different from their residence in a circular pattern, leaving home to work and returning home after work (Tambunan, Syaukat, Arlina, and Hashilah, 2014). 
Commuting offers opportunities for individuals in the household to work in areas that are administratively different from where they live. Commuting also encourages women who are generally second breadwinners in the household to work without abandoning their role as housewife. The farther away the residence is from the business center the more the cost of travel will increase, but housing prices will be lower. However, husbands and wives who are both breadwinners in the household will make individual trade-offs between the commute time and wages. Higher wages will increase housing demand and will also increase the monetary value of commute time costs (White, 1977).

The increasing role of women in the labor market is also creating households with married couples who both work (dual-worker households). However, the experience of women in the workforce is significantly different from that of men. Women earn lower incomes, work in various jobs and industries, and work shorter hours. The percentage of men who work full time is higher than that of women. More women choose to work part time than men. In general, women work shorter hours than men (BPS, 2017).

The traditional theory of perspective workers explains that as the primary breadwinner, the husband determines the location of the permanent job and decides how to maximize the location of housing, whereas married women determine the location of the residence and maximize the place of work (Singell and Lillydahl, 1986). Dual-worker households that commute to the workplace will find it more difficult to determine the location of the residence (Hong, Lee, and McDonald, 2018).

Commute time will reflect the need of individuals to use time allocations both for themselves and for the household. The stereotype is that women are basically identified with domestic or household activities. Most household responsibilities, such as the time spent on housework and childcare, continue to be carried out by women. The existence of a dual role of women as breadwinners and as housewives causes women who work to be more sensitive to distance than men. Women's sensitivity to the distance from home to various work locations plays a role in the occupational segregation of women (Hanson and Hanson, 1980).

Married women who decide to enter the workforce will balance wages and non-monetary benefits with the costs of activities that must be sacrificed if working outside the home. These lost activities include domestic work, childcare, or leisure time. Household financial conditions will also affect a woman's decision to work. For low-income households, additional income will be very beneficial, so this will encourage women to work. Whereas in households with high incomes, there is no pressure for women to provide additional income for their households. Stigma and social norms in society related to a women's mobility or the type of work that is suitable for women also affect a woman's decisions to work (Schaner and Das, 2016).

Most of the previous research was limited to the determinant analysis of individual commuter trips rather than dual-worker commuter behavior. Research on the time required to travel to work in metropolitan areas in Indonesia shows that men tend to take longer trips in almost all cities except Sarbagita and Jabodetabek. Meanwhile, married women face time limitations and geographical restrictions in their work activities. This data supports substantially increasing mobility to the workplace to overcome the problem for women of differences in the distance between residence and work or other activities. Several commute time surveys in developing countries show that there is still a gender gap in commute time. The results of the studies show that men devote more time to travel to the office and that this difference remains relatively constant over time. Previous studies also noted that the average distance and travel time for women tended to be shorter than for men and made it harder for women to work away from home (Gimenez-Nadal and Molina, 2016; Madden, 1981; Sahara, 2010).

Research related to household commuter patterns has been carried out in Europe and the United States, but similar research is still rare in developing countries. This study aims to examine empirically that residence decisions refer to differences in income. The question is whether a husband with higher income tends to choose a place to live closer to the workplace so that he only needs to take a shorter trip or just the opposite. The second objective is to find out how socio-economic characteristics affect the commute time of a dual-worker couple.

\section{LITERATURE REVIEW AND HYPOTHESIS DEVELOPMENT}

\subsection{Commute Time and Income}

Commute time is the time required by commuters to travel from their residences to the workplace. Commute time for urban workers is difficult to express in a model because it lies in a cross section between urban economic theory and employment economic theory about spatial patterns of the location of workplaces and housing (White, 1986).

The monocentric model developed by Alonso (1964) explains that workers will choose between short commute times and cheaper housing locations. Workers who live close to the business center will take shorter trips to the office, so the demand for housing in these locations is very high. Meanwhile, in the suburbs, housing prices are cheaper. 
The bid-rent curve explains the demand for land by connecting the price of land rent that an individual can pay at a certain distance that achieves maximum satisfaction. The bid-rent curve assumes that individuals must go to a point that is the center of business in urban areas for work. This curve also assumes that the direct cost of mobility is positively related to distance and has a negative relationship with housing rental. This means that if the distance of the settlement is further from the city center, the rent for the land will be lower because of the greater transportation costs that must be incurred by individuals to get to the city center (Alonso, 1964).

The choice of the location of the residence assumes that people with different incomes will have different location preferences. There is an assumption that society consists of three income groups, namely low-, middle-, and high-income groups. Figure 1 depicts land ownership in several cities in North America. The lowincome group holds land between $\mathrm{M}$ and $d_{l}$; the land owned by the middle-income group extends from $d_{l}$ to $d_{m}$; and the land owned by the high-income group extends to $d_{h}$.

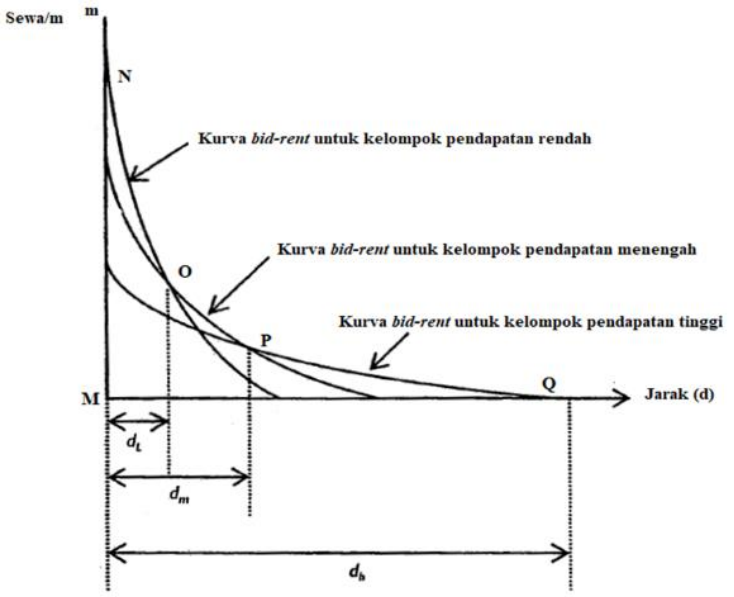

Figure 1 Housing locations for different income groups. Source: Mccann (2001).

Low-income groups choose to live near business centers to reduce transportation costs. High budget constraints and the limited ability to pay transportation costs are the reasons for low-income groups to live near business centers, so they need only a short time to go to work. The middle- and upper-income groups are assumed to have sufficient income to pay transportation costs. Thus, when income rises, individual preferences for land increase. The increase in income obtained is only in accordance with the price of land in the suburbs, which is cheaper than in the city center.

Despite the groupings described earlier, assumptions regarding relative preferences for space and accessibility may not always be correct. In some situations, the income elasticity of accessibility is generally greater than the income elasticity for space demanded. In this case, high-income groups will live in the city center, middle-income groups will live in areas directly adjacent to the city center, and low-income groups are located in the suburbs. The suburbs that will be inhabited by low-income groups will be determined in connection with the commuter costs that will be incurred. Cities with severe traffic congestion due to inadequate infrastructure restrict people to traveling even shorter distances. The opportunity cost of commute time becomes very high for all groups of wage earners, especially for high-income groups who respond by buying land in the city center (Mccann, 2001).

Research using the commute to and from work time difference between a husband and wife in a dual-worker household empirically tests the proposition that the decision to determine the location of the residence is made because of the husband's work location. When the husband's income increases relative to the wife's income, the husband's commute time also gets longer while the wife's commute time decreases. Although the difference is small, an increase in the husband's wage increases the difference in commute time and an increase in the wife's wage reduces the difference in commute time. On the other hand, when the wife earns more than her husband, her travel time to work increases while her husband's declines even though the percentage is still lower than the commute time of the husband who has a higher income (Singell and Lillydahl, 1986; Lee and McDonald, 2003; Hong, Lee, and McDonald, 2018; Hanson and Johnston, 1985).

Research in the United States on travel time to work carried out by Gordon, Kumar and Richardson (1989) shows results that differ from theories related to female commuter patterns. Short travel time to work is only found in women with the highest incomes. However, commuter workers with high incomes, both men and women will be free from income restrictions that limit the choice of location of residence. They freely determine the location of housing closer to work.

Glaeser, Kahn and Rappaport (2008) found that in the United States higher income workers tended to live in the city center close to business centers to reduce travel time. Mok (2007) also explained that a higher husband's income would increase the wife's likelihood of choosing to live close to their workplace so that the wife had a shorter commute time. However, a wife's greater income often results in a reduced tendency for a shorter wife commute. Thus, the first hypothesis is:

H1: The income of a husband and wife in a dualworker household has a positive impact on their different commute time.

\section{Commute Time and Socio-demographic Variables}

Findings in the United States conclude that the characteristics of workers who travel longer to work are men with higher incomes who own their own homes. 
Higher incomes are related to job status. Self-employed workers travel shorter distances workplaces than employees. Workers with self-employment status have the flexibility to determine when to leave for work to avoid peak commute times. Workers with higher incomes tend to live in city centers that are close to business centers to reduce travel time (Singell and Lillydahl, 1986; Gordon, Kumar and Richardson, 1989).

Working hours also affect commute time. Workers with longer commute times will increase their weekly work hours by increasing daily labor supply (Gutiérrezi-Puigarnau and van Ommeren, 2010). A similar study was conducted by Sultana (2008) that showed that the working hours of dual-worker couples were quite important in influencing the commuter travel time of working couples. Commute time of working partners becomes shorter when one of the partners, in this case, the wife works part time.

Wang and Qin (2017) investigated commuting couples in Beijing and also concluded that wives commute shorter distances than their husbands, but the difference gets smaller when a wife's education level is higher than the husband's. Research conducted by Lee and Mcdonald (2003) in South Korea also shows that the level of education influences the commute time, which serves as a proxy for wage rates. Workers with low education levels tend to have a shorter commute time than workers with higher levels of education.

Commute time can also be influenced by formal (normal hours and regular wages) and informal (untaxed and unmonitored) employment status. From Lee and Mcdonald's (2003) research, it can be concluded that workers in the formal sector have a longer commute than workers in the informal sector. Workers in the formal sector commute for 9 minutes longer than workers in the informal sector. Male full-time workers are more likely to work in the city center while women are more likely to be employed in the suburbs. The impact of residence in the central city is stronger for men who work full time than for women. Giuliano's (1998) research in Los Angeles found that the longer pattern of commute mobility was related to the status of formal employment. Workers in the formal sector travel to work 4 minutes longer than workers in the informal sector. Thus, the second hypothesis is proposed:

$\mathrm{H} 2$ : The difference in socio-economic variables between husband and wife in dual-worker household influences their different commute time.

\section{RESEARCH METHODS}

\subsection{Data and Samples}

The data used in this study was the 2018 National Labor Force Survey (Sakernas) conducted by the Central Bureau of Statistics Indonesia. Sakernas 2018 sample subjects are residents 15 years old and over. The sample subject used for this study were workers who commuted and were married. The subjects were husband and wife couples where both live in the household. Meanwhile, supporting data on the price of renting a house in a regency or city came from the results of the 2017 National Socio-Economic Survey (Susenas)

\section{Research Model}

The model used in this study are as follows:

$$
Z_{1(x)}=\ln \left[\frac{P(Y=1 \mid x)}{P(Y=0 \mid x)}\right]=\beta_{10}+
$$$$
\beta_{11} \text { INCgap }+\beta_{12} \text { WHdiff }+\beta_{13} \text { STATdiff }+
$$$$
\beta_{14} \text { MIGRANT }+\beta_{15} \text { AGEgap }+\beta_{16} \text { EDUgap }+
$$

$$
Z_{2(x)}=\ln \left[\frac{P(Y=2 \mid x)}{P(Y=0 \mid x)}\right]=\beta_{20}+
$$
$\beta_{21}$ INCgap $+\beta_{22}$ WHdiff $+\beta_{23}$ ST ATdiff + $\beta_{24}$ MIGRANT $+\beta_{25}$ AGEgap $+\beta_{26}$ EDUgap + $\beta_{27} H O M E+\beta_{28} R E N T+\varepsilon$

Where:

WHdiff: Work hours differences

STATdiff: Work status differences

MIGRANT: Migrant status

$\begin{array}{ll}\text { AGEgap: } & \text { The age gap } \\ \text { EDUgap: } & \text { Education gap } \\ \text { HOME: } & \text { Residence Location } \\ \text { RENT: } & \text { Price of rent house }\end{array}$

\subsection{Operationalization of Variables}

\subsubsection{Commute Time}

The dependent variable used in this study was the difference in commute times between the husband and wife in a dual-worker household. Commute time is the time it takes to travel back and forth from home to work. The unit of analysis is the husband and wife pair whose places of residence and places of work differ administratively at the district or city level. In the morning they go to work; in the afternoon they return home.

\subsubsection{Income Gap}

The difference in wages or net salary in the form of money received by couples who worked in the past month at the main jobs and were paid in the form of money or goods: The survey responses were: 1 if the husband's income is higher; 2 if the wife's income is 
higher; 3 if there is no difference in income between husband and wife.

\subsubsection{Work Hours Differences}

Differences in the length of time worked in hours for the husband and wife, not including the rest hour during the past week. The survey responses were: 1 if the husband's works hours are longer than the wife's; 2 if the wife's work hours were longer than the husband's work hours; 3 if there was no difference in work hours between husband and wife.

\subsubsection{Work Status Differences}

Differences in employment status between husband and wife. The survey responses were: 1 if the husband worked formally and the wife worked informally; 2 if the wife worked formally and the husband worked informally; 3 if husband and wife both worked formally; 4 if husband and wife both work informally.

\subsubsection{Migrant Status}

The differences in dual-worker household's current residence compared to the residence 5 years ago. The survey responses were: 1 if the husband has moved at least once in the last 5 years; 2 if the wife has moved at least once in the previous 5 years; 3 if the husband and wife have moved at least once in the last 5 years; 4 if the husband and wife never moved.

\subsubsection{The Age Gap}

The age gap between husband and wife in a dualworker household. The survey responses were: 1 if the husband age is older than the wife; 2 if the wife is older than the husband; 3 if there is no age difference between the husband and the wife.

\subsubsection{The Education Gap}

Differences in the level of education between husband and wife in a dual-worker household. The survey responses were: 1 if the husband's education is higher than the wife's; 2 if the wife's education is higher than the husband's; 3 if both husbands and wives are highly educated; 4 if both husbands and wives are equally low educated.

\subsubsection{Residence Location}

This segment measures whether or not a dual-worker household currently living in a metropolitan area. The survey responses were: 1 if the location of the residence is in the city core; 2 if the place of residence is not in a metropolitan area.

\subsubsection{Rental House}

Monthly price of a rental house in a regency or city, paid in Rupiah.

\section{RESULTS AND DISCUSSION}

\subsection{Descriptive Statistics}

The commute time of a married couple is the length of commute time required by the husband and wife to arrive at work during the past week of the survey. Table I describes the difference in commute time between husband and wife in dual-worker households according to income received. Income as the primary independent variable received by husband and wife from work for a month based on 2018 Sakernas data.

Table 1. Distribution of percentage of commute time for couple commuters in dual-worker households by income.

\begin{tabular}{|c|c|c|c|c|}
\hline \multirow{2}{*}{ Difference Income } & \multicolumn{3}{|c|}{ Commute time for Couple in a Dual-Worker Household } \\
\cline { 2 - 5 } & $\begin{array}{c}\text { Husband's commute } \\
\text { time is longer }\end{array}$ & $\begin{array}{c}\text { Wife's commute } \\
\text { time is longer }\end{array}$ & $\begin{array}{c}\text { There is no difference in } \\
\text { commute time between } \\
\text { husband and wife }\end{array}$ & $\begin{array}{c}\text { Total } \\
\text { Husband's income is higher }\end{array}$ \\
\hline Wife's income is igher & 9.90 & 4.80 & 82.00 & 100.00 \\
\hline $\begin{array}{c}\text { There is no difference in income } \\
\text { between husband and wife }\end{array}$ & 7.70 & 8.30 & 81.80 & 100.00 \\
\hline
\end{tabular}

The commute time in a dual-worker household in Table I is defined by the time spent commuting from the place of residence to the workplace. Based on the differences in income received by dual-worker couples, it can be seen that for all categories of income differences, the majority do not have gaps in commute time between husband and wife. However, when the income of one of the pairs is higher, the commute time tends to be longer for the recipient of the higher income.

\subsection{The Multinomial Regression Result}

The multinomial logistic regression results show that the independent variables had a statistically significant effect on the differences in commute time of couples in dual-worker households in almost all categories. However, several independent variables have no significant effect. We used Likelihood Ratio Test to test 
the significance of each independent variable. Variables that significantly affected the model were differences in income, in work hours, and in employment status. Differences in education, residence location, and house rental prices also affected the model.

When the income difference variable is the main independent variable, income differences have a significantly positive influence on the differences in dual-worker commute times in almost all categories. Husbands with higher incomes tend to commute longer than husbands with the same income as their wives. Likewise, if the wife has a higher salary than the husband, the commute time is longer than for the wife who receives the same income as the husband.

Wives who have greater income than their husbands in dual-worker households have a tendency to travel to work for longer hours compared to husbands and wives in dual-worker households who have the same income. The commute time of the wife whose income is greater than her husband's has a positive relationship with the husband's travel time. Wives who have higher incomes than husbands tend to increase their husband's commute time compared to husbands and wives in dual-worker households who have the same income.

The results of this study indicate that when a wife's income is greater, the husband can reduce his commute time, which shifts a greater share of the household tasks to the husband. A higher husband's income will increase the wife's likelihood of choosing a place of residence close to her workplace so that only the wife has a shorter commuter time. However, a larger wife's income reduces the tendency for a shorter wife's commuter time.

Variable differences in work hours have a statistically significant effect on differences in the travel times of couples in dual-worker households. In marriages in which either the husband or the wife works longer hours, there is a tendency to take longer times to travel to work. Opportunities for commuting are almost the same for each category, but husbands in households with husbands working longer hours than wives tend to travel to work longer than husbands in households where both are equally has same working hour. Furthermore, the variable that is statistically significant in almost all categories are variable levels of education. Husbands in households where both are equally well educated have a tendency to have longer commute times than those with lower education than the wife. Meanwhile, wives in households with husbands who have a higher education have a lower chance of taking longer commute times compared to those with lower education than the husband. When husband and wife have higher education, the commute time for both husband and wife is longer than for households where neither spouse has a higher education. When both partners have a higher level of education, household income is higher and thus their demand for housing is greater.

The next statistically significant variable is employment status. Husbands in dual-worker households with formal working status and wives who work informally have a greater tendency to travel to the workplace longer than husbands in households where couple works informally. This proves that a longer commute time is associated with men and formal employment status.

Furthermore, residential areas also have a significant influence on commute time in dual-worker households. Dual-worker households that live in metropolitan areas have less chance of traveling longer to the office than households living in suburban areas. This proves that couples living in metropolitan cities tend to take shorter trips to work.

Home rental price variables also have a significant influence at the 10 percent confidence level for differences in commute time in dual-worker households. Each increase of $\mathrm{Rp} 100,000$ in the price of a rental house will increase the chances of a husband's commute time being longer by 0.2 and of the wife's commute time being longer by 0.3 . This is in line with previous research that proved that the more expensive housing prices in a region would encourage workers to look for a house at a lower price even though they have to take a longer time to work.

\section{CONCLUSION AND IMPLICATIONS}

This study concludes that commute time differences in dual-worker households are significantly affected by differences in income, housing rental prices, differences in working hours, differences in employment status, differences in education, and the location of the residence.

Increasing income will increase the length of commute time to work for both husband and wife. Husbands with higher incomes tend to take longer trips than husbands who have the same income as their wives. Likewise, if the wife has a higher income than the husband, the tendency to commute is longer than for the wife who receives the same income as the husband.

The results of this study illustrate that in Indonesia the longer commute time in dual-worker households is associated with the conditions where income is high, the commuters are husbands who have longer working hours, work in the formal sector, have higher educations, and live in a metropolitan area. The results of this study are also in line with the theory presented by Alonso (1964) that explains that workers will choose between short commute times and cheaper housing locations. As incomes increase, workers tend to look for larger houses, so they decide to find places with more 
affordable housing prices even though they have to travel longer.

Based on these conclusions, the recommendation has been made that the government needs to disseminate information related to Jasa Raharja insurance that provides protection to users of public and private transportation. This needs to be done so that the commuter feels safe during the trip. The government also needs to pay attention to the informal sector, which is able to accommodate workers who do not find work in the formal sector. The government can provide training that can improve the skills of these workers. Loan assistance and appropriate technology can greatly assist businesses in the informal sector.

Infrastructure development such as repairing and widening roads and toll road construction, as well as the addition of high-speed railways that can support the commuters who have chosen to live in a different location from the workplace.

\section{RESEARCH LIMITATIONS}

The limitation of this study lies in the lack of household variables such as the presence of young children, which can affect the time allocations for couples who work, especially the wives. This is because the data are Sakernas data, and the respondents were residents 15 years old and over. Another limitation is that the data used is cross-section data, so this study could not measure how much effect differences between husband and wife had on the decision to commute. This study also does not examine the difference in commute time between workers and non-workers so that the issue of selection bias cannot be avoided.

\section{REFERENCES}

[1] Alonso, W. Location and land use: Toward A general theory of land rent. Harvard University Press, Cambridge, 1964.

[2] BPS. 'Persentase Penduduk Daerah Perkotaan menurut Provinsi’ 2010-2015 2019. .

[3] BPS Keadaan angkatan kerja di Indonesia 2017. Badan Pusat Statistik, Jakarta, 2017.

[4] Gimenez-Nadal, J. I. and Molina, J. A. 'Commuting time and household responsibilities: evidence using propensity score matching'. Journal of Regional Science, 56(2), 2016, pp. 332-359.

[5] Giuliano, G. 'Information Technology, work patterns and intrametropolitan location: A case study'. Urban Studies, 35(7), 1998, pp. 1077-1095.

[6] Glaeser, E. L., Kahn, M. E. and Rappaport, J. 'Why do the poor live in cities? The role of public transportation'. Journal of Urban Economics,63(1), 2008, pp. 1-24.

[7] Gordon, P., Kumar, A., H. W. and Richardson 'Gender differences in metropolitan travel behaviour'. Regionální Studia, 23(6), 1989, pp. 499-510.

[8] Gutiérrez-i-Puigarnau, E. and van Ommeren, J. N. 'Labour supply and commuting'. Journal of Urban Economics, 68(1), 2010, pp. 82-89.

[9] Hanson, S. and Hanson, P. 'Gender and urban activity patterns in Uppsala, Sweden'. Geography Review, 71(3), 1980, pp. 221-299.

[10] Hanson, S. and Johnston, I. 'Gender differences in work-trip length: explanations and implications'. Urban Geography, 6(3), 1985, pp. 193-219.

[11] Hong, S. H., Lee, B. S. and McDonald, J. F. 'Commuting time decisions for two-worker households in Korea'. Regional Science and Urban Economics, 69, 2018, pp. 122-129.

[12] Lee, B. S. and McDonald, J. F. 'Determinants of commuting time and distance for Seoul residents: the impact of family status on the commuting of women'. Urban Stud., 40(7), 2003, pp. 1283-1302.

[13] Madden, J. F. 'Why women work closer to home'. Urban Studies, 18(2), 1981, pp. 181-194.

[14] McCann, P. Urban and regional economics. Oxford University Press Inc., New York, 2001.

[15] Mok, D. 'Do two-earner households base their choice of residential location on both incomes?'. Urban Studies, 44(4), 2007, pp. 723-750.

[16] R. P. Tambunan, Chotib, S. F. Syaukat, Y. Nurraini, D. Arlina, and F. Hashilah, Urban Demografi. Jakarta: Kemitraan Agenda Habitat Indonesia, 2014.

[17] Sahara, I. Pola waktu Tempuh pekerja dalam melakukan mobilitas ulang-Alik di kota Metropolitan indonesia tahun 2008'. Universitas Indonesia, Depok, 2010.

[18] Schaner, S. and Das, S. 'Female labor force participation in Asia: Indonesia country study'. Adb Econ. Work. Pap. Ser., no. 474, 2016.

[19] Singell, L. D. and Lillydahl, J. H. 'An empirical analysis of the commute to work patterns of males and females in two-earner households'. Urban Studies, 23(2), 1986, pp. 119-129.

[20] Sultana, S. 'Effects of married-couple dual-earner households on metropolitan commuting: evidence from the Atlanta metropolitan area'. Urban Geography, 26(4), 2008, pp. 328-352. 
[21] Wang, L. and Qin, P. 'Distance to work in Beijing: institutional reform and bargaining power'. Urban Studies, 54(6), 2017, pp. 1385-1406.

[22] White, M. J. 'A model of residential location choice and commuting by men and women workers'.
Journal of Regional Science, 17(1), 1977, pp. 4152.

[23] White, M. J. 'Sex differences in urban commuting patterns'. American Economic Review, 76(2), 1986, pp. 368-372. 